\title{
Human $\beta$-2 Defensin in Tinea Versicolor and Tinea Circinata
}

\author{
AMR A. RATEB, M.D.*; AMIRA M. EL TAWDY, M.D.*; FAISAL NOUR EL DIN, M.D.**; \\ RANA ABD ELAZEEM HAMMAD, M.Sc.**; KHALDA S. MOHAMED, M.D.*** and \\ DINA M. SALAMA, M.D.* \\ The Department of Dermatology, Faculty of Medicine, Cairo University* and National Research Center** and \\ Molecular Genetics Department, National Research Center***
}

\begin{abstract}
Background: Both superficial tinea and pityriasis versicolor are very popular fungal skin infections that affect people all over the world. Recent research suggests that certain antimicrobial peptides can also play a role in the body's natural defense against fungal infection.

Aim of Study: The purpose of the current research would be to investigate the tissue expression of $\beta 2$-defensin mRNA in lesions of tinea versicolor and lesions of tinea circinata and hence studying its role in fungal infection pathogenesis.

Patients and Methods: Twenty patients with tinea versicolor, twenty with tinea circinata, and twenty controls were included in this case control study. For real-time PCR (RTPCR) gene expression of $\beta 2$-defensin mRNA, a punch skin biopsy was obtained from the patient's lesional and nonlesional skin, as well as normal skin from a control.

Results: $\beta 2$ defensin was upregulated in lesional areas of tinea versicolor and tinea circinata in comparison to non lesional areas of tinea versicolor, tinea circinata and control. These results reached a statistical significance for mRNA $\beta 2$ defensin in tinea versicolor and tinea circinata ( $p$-value $<0.014)$.

Conclusion: The results back up the theory that antimicrobial peptides ( $\beta 2$-Defensin) may help the skin fight dermatophytes and $\mathrm{M}$. furfur.
\end{abstract}

Key Words: $\beta 2$-defensin - Tinea circinata - Tinea versicolor.

\section{Introduction}

ANTIMICROBIAL peptides (AMPs), as well known as host defense peptides (HDPs), play a significant role in the innate immune response. These peptides are antibiotics with a wide spectrum of activity that have the potential to be used as new therapeutic agents. Gram-positive and negative bacteria, enveloped viruses, fungi, and even transforming or cancerous cells have all been shown to be killed by antimicrobial peptides [1].

Correspondence to: Dr. Amr A. Rateb, The Department of Dermatology, Faculty of Medicine, Cairo University
Small cysteine-rich cationic proteins present in both vertebrates and invertebrates are known as defensins. They've also been found in plants $[2,3]$ Host defense peptides are what they are, and what they do. They destroy bacteria, fungi, and a wide range of enveloped and non-enveloped viruses.

Human cells have lately been found to contain three $\beta$-defensins of epithelial origin: Human $\beta$ defensin 1 (HBD-1), HBD-2, and HBD-3 [4,5] .

The first human $\beta$-defensin (hBD1) has been isolated from the hemofiltrate of dialysis patients. hBD1 is found in epithelia which are directly subjected to the environment or microbial flora (e.g. in the lung, kidney, pancreas, prostate, salivary gland, and mammary gland) [6] .

hBD2, a second member of the family, was discovered in psoriatic skin for the first time. Epithelia (gut, lung, urogenital system, skin and pancreas), leukocytes, and bone marrow all express hBD2. In contrast to hBD1, epithelial tissue exposed to LPS or pro-inflammatory agents (TNF$\alpha$ or IL1b) upregulates hBD2 expression. Another defensin (hBD3) has been isolated from human lesional psoriatic scales and cloned from keratinocytes. Microbicidal activity of hBD1 and 2 is primarily directed against Gram-negative bacteria, with little to no activity directed against Grampositive bacteria. hBD3 seems to be a broadspectrum peptide antibiotic which destroys a wide range of potentially pathogenic bacteria as well as opportunistic pathogenic yeast, Candida albicans. hBD3 is caused by inflammatory stimuli including the TNF- $\alpha$ and bacteria contact, much like hBD2. The skin and tonsils were discovered to be the main tissues that expressed hBD3 mRNA [7]. 


\section{Aim of the study:}

The purpose of the current research would be to investigate the tissue expression of $\beta 2$-defensin mRNA in lesions of tinea versicolor and lesions of tinea circinata and hence studying its role in fungal infection pathogenesis.

\section{Patients and Methods}

This research was conducted on patients suffering from tinea versicolor and tinea circinata presenting to the Dermatology Outpatient Clinic at Cairo University's Kasr El Eini Faculty of Medicine in 2017. The study included forty patients of tinea versicolor and tinea circinata $[20$ patients tinea versicolor and 20 patients tinea circinata (twenty males and twenty females)] their ages varied from 16 to 38 , with the average being 25 . Diagnosis was made on clinical basis, and also the study included 20 control (healthy individuals suffering from hair fall). Written informed consents were signed by all patients and controls after they were approved by the Dermatology Research Ethical Committee Office, Faculty of Medicine, Cairo University, and the National Research Center Ethical Committee.

Cases were chosen from the Dermatology outpatient clinic according to the following criteria including all ages, sexes, whatever first attack or recurrent attack.

Patients were subjected to full medical history including personal, present (onset, course and duration) as well as past and family history.

No associated diseases were found among the patients group.

\section{Tissue sample collection and RNA extraction:}

Two skin biopsies ( $5 \mathrm{~mm}$ punch) were taken from every patient (a lesional biopsy and non lesional one). One skin biopsy was taken from control. Sterilization of skin surface with alcohol swabs was done and the skin surface was anaesthetized with $2 \%$ lidocaine. The skin punch was taken perpendicularly to the skin surface, turned clockwise, and progressed till it reached a depth of $5 \mathrm{~mm}$. Over the wound, a bandage was put on. Patients were told to change their bandages every day until the wound healed completely.

The biopsies were subjected to molecular analysis by RNA extraction of Beta2 Defensin genes then amplification of Beta2 Defensin gene by real time 'quantitative' polymerase chain reaction (PCR).

Total RNA was extracted utilizing Trizol as directed by the manufacturer to detect mRNA expression (Applied BioSystems). cDNA was carried out in a total volume 20 L R reaction, 10 L Thanan universal PCR master mix (10 M) 1 f arward primer (10 M) 1 r r werse primer (10 M) and 14.84 distilled water made up the total PCR volume of 25 PCR cycling conditions were as follows: Denaturing at $94^{\circ} \mathrm{C}$ for 20 seconds, then annealing at $56^{\circ} \mathrm{C}$ for 20 seconds, and extension at $72^{\circ} \mathrm{C}$ for 30 seconds, then $80^{\circ} \mathrm{C}$ for 20 seconds. The primers were as follows:

GAPDH (141 pb): sense, 5'-CCTCAAGATCATCAGCAAT-3'; antisense, 5'CCATCCAGTCTTCTTCTGGGT-3'; probe,

\section{5'-FAM-ACCACAGTCCCATGCCAT- CATCAC-FAM-3'}

\section{Statistical analysis:}

When applicable, data were statistically defined using range, mean \pm standard deviation $( \pm \mathrm{SD})$, median, frequencies (number of instances), and percentages. The Anova test for independent samples was used to compare quantitative variables among the study groups. Wilcoxon Signed Ranks test was used to compare categorical data. The Pearson correlation coefficient test was used to determine the association between different variables. A statistically significant $p$-value was less than 0.05. Microsoft Excel 2007 (Microsoft Corporation, NY, and USA) and SPSS (Statistical Package for the Social Science; SPSS Inc., Chicago, IL, USA) version 15 for Microsoft Windows were used to perform all statistical analysis.

\section{Results}

This research included forty patients (20 patients with tinea versicolor and 20 patients with tinea circinata). The patient group included 20 men $(50 \%)$ and 20 women $(50 \%)$. Their ages varied from 16-38 years, with an average of $24.93 \pm 6.635$ years, with duration from 7 days to 3 months.

On comparing the level of expression of mRNA $\beta 2$-defensin lesional and non lesional in both tinea versicolor and tinea circinata patients, a significant statistical difference was reported (higher in lesional areas). ( $p$-value 0.014) (Table $1 \&$ Fig. 1).

A significant difference in the level of $\beta 2$ defensin mRNA was detected in both tinea versicolor and tinea circinata compared to the control group, where lesional areas were much higher. ( $p$ value $<0.001$ ) (Table $2 \&$ Fig. 2). 
Table (1): Comparison between Beta2 Defensin mRNA expression lesional and non lesional in tinea versicolor and tinea circinata.

\begin{tabular}{|c|c|c|c|}
\hline & $\begin{array}{c}\text { Beta2 defensins } \\
\text { Lesional }\end{array}$ & $\begin{array}{c}\text { Beta2 defensins } \\
\text { Non Lesional }\end{array}$ & $\begin{array}{c}p- \\
\text { value }\end{array}$ \\
\hline $\begin{array}{l}\text { Tinea } \\
\text { versicolor }\end{array}$ & $\begin{array}{l}\text { Range: } 2.74-8.26 \\
\text { Mean } \pm \text { SD: } \\
4.7210 \pm 1081113\end{array}$ & $\begin{array}{l}\text { Range: } 0.59-21.00 \\
\text { Mean } \pm \text { SD: } \\
2.7665 \pm 4.82321\end{array}$ & 0.014 \\
\hline $\begin{array}{l}\text { Tinea } \\
\text { circinata }\end{array}$ & $\begin{array}{l}\text { Range: } 1.82-8.71 \\
\text { Mean } \pm \text { SD: } \\
13.6850 \pm 39.58097\end{array}$ & $\begin{array}{l}\text { Range: } 0.20-147.00 \\
\text { Mean } \pm \text { SD: } \\
3.6510 \pm 1.45465\end{array}$ & 0.014 \\
\hline
\end{tabular}

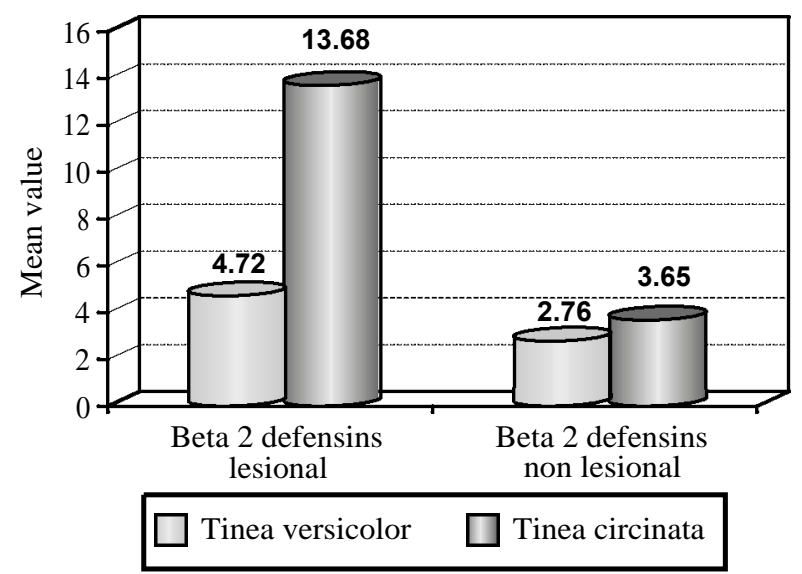

Fig. (1): Comparison between Beta2 Defensin mRNA expression lesional and non lesional in tinea versicolor and tinea circinata.

Table (2): Comparison between Beta2 Defensin mRNA expression lesional tinea versicolor, tinea circinata and control group.

\begin{tabular}{llll}
\hline & $\begin{array}{c}\text { Beta2 defensins } \\
\text { Lesional }\end{array}$ & \multicolumn{1}{c}{ Control } & $\begin{array}{c}p \text { - } \\
\text { value }\end{array}$ \\
\hline Tinea & Range: $2.74-8.26$ & Range: 0.40-2.02 & $<0.001$ \\
versicolor & Mean \pm SD: & Mean \pm SD: & \\
& $4.7210 \pm 1081113$ & $0.9765 \pm 0.42948$ & \\
Tinea & Range: $1.82-8.71$ & Range: 0.40-2.02 & $<0.001$ \\
circinata & Mean \pm SD: & Mean \pm SD: & \\
& $3.6510 \pm 1.45465$ & $0.9765 \pm 0.42948$ & \\
\hline
\end{tabular}

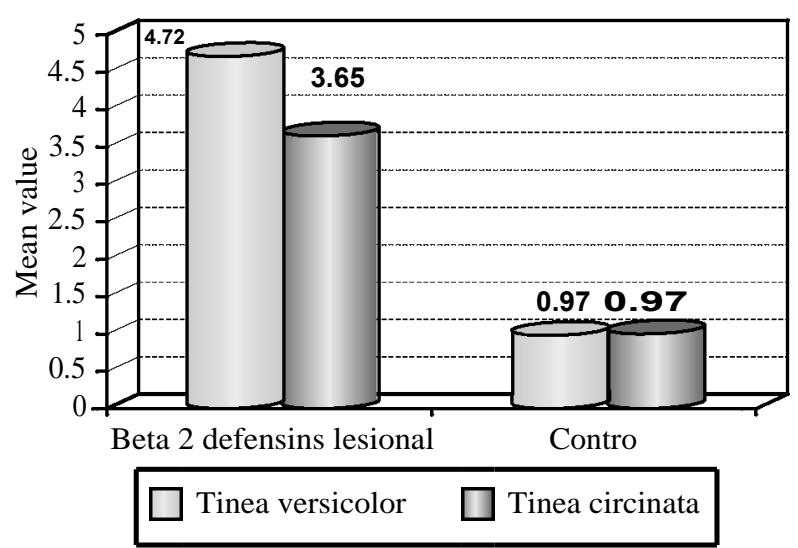

Fig. (2): Comparison between Beta2 Defensin mRNA expression lesional tinea versicolor, tinea circinata and control.

\section{Discussion}

Both superficial tinea and pityriasis versicolor are very popular fungal skin infections that affect people all over the world. In most instances, the causal dermatophytes and Malassezia spp. spread throughout the epidermis' stratum corneum. A moderate inflammatory response is routinely noticed during infection. A mild dermal infiltrate of mononuclear cells and polymorphous leucocytes characterizes this response. The skin-invading fungi are usually confined to the stratum corneum, even though only a few of such inflammatory cells enter the superficial skin layers. This indicates that the skin may harbour natural non-cellular components against fungi [9-13].

Recent research suggests that certain antimicrobial peptides can play a role in the body's natural defense against fungal infection $[\mathbf{1 1 , 1 2 , 1 3 ]}$.

Epithelia and granulocytes produce antimicrobial molecules, putting them in a unique place to defend against non-invasive organisms like dermatophytes. Dermatophytosis is caused by Trichophyton, Epidermophyton, and Microsporum species. The keratinized tissues of the epidermis, hair, and nails are infected by these keratinophilic filamentous fungi, frequently; there is just a minor inflammatory response. Spite of the fact that they are often infected in people who seem to have normal immune systems, the cause of this deficiency in such patients that makes them vulnerable to infection is unclear [14].

Human cells have lately been found to contain three $\beta$-defensins of epithelial origin: Human $\beta$ defensin 1 (HBD-1), HBD-2 and HBD-3 [4,5]

The objective of this research was to investigate the possible role of AMPs (beta defensin 2) for defending against cutaneous fungal diseases.

Expression of mRNA $\beta$-defensin 2 was assessed (by RT-PCR) in lesional and non lesional areas in patients having tinea versicolor and others having tinea circinata and in 20 healthy control subjects.

Out of the forty patients involved in the study a statistical significant increase of the level of HBD2 was reported in all patients (in lesional areas) compared to the control group (in 20 individuals).

Similar results have been reported before in previous studies but mostly using immunostaining of skin biopsies. They revealed a significant increased expression of AMPs (HBD2) in the distinct 
layers of lesional epidermis when compared to the control group $[\mathbf{1 5 , 1 6 , 1 7 ]}$

Donnarumma et al. [18] measured the expression of mRNA by RT-PCR as we did and reported as well increased level of both HBD 1 and HBD2 in human keratinocytes treated by malassizia furfur (tissue culture not patients).

Again the significant statistical reported differences for AMPs in this current study between lesional and that of the non lesional areas in the same patient being higher in lesional areas assures more that AMPs ( 3 -defensin) resemble an integral part of the innate immunity expressed in a specific form in skin areas only where the fungus resides causing the resultant pathology.

Dermatophytes and yeast are two different forms of fungal organisms causing tinea circinata and tinea versicolor respectively. Hence we investigated the expression of AMPs in both diseases to elaborate any possible difference in the immunogenic reaction related to the type of the fungal organism.

Supporting these results, both Lopez Garcia et al. [16] and Brasch et al. [17], measured HBD2 \& HBD3 in both superficial fungal infections (tinea corporis) and tinea vesicolor (in 17 patients) and found no significant differences as well.

Recurrence is a usual feature encountered in patients suffering from fungal infection especially seen in tinea versicolor patients.

02-defensin level was significantly higher in females in comparison to males. Otherwise no significant correlation was detected in the present study between the studied AMPs and other clinical parameters e.g age, duration and the extent of the disease.

In conclusion, the current study revealed significant higher levels of mRNA of 02-defensin in tinea versicolor and tinea circinata patients, highlighting their importance as an integral part of innate immunity to defense against superficial fungal infection. As a result of this theory, new therapeutic pathways and methods to recognizing human susceptibility to such rare dermatologic diseases are suggested.

\section{Conclusion:}

The results back up the theory that antimicrobial peptides (P2-Defensin) play a role in skin protection against dermatophytes and M. furfur.
Further study for other AMPs \& their role in fungal infection. Study of any possible genetic polymorphism for AMPs in recurrent cases. Comparing the role of AMPs in different skin infections (bacterial, viral and fungal). A larger scale of patients to investigate more the sex differences reported in this current study regarding the levels of mRNA expression of b2-defensin being higher in females.

\section{References}

1- REDDY K.V., YEDERY R.D. and ARANHA C.: "Antimicrobial peptides: Premises and promises". International Journal of Antimicrobial Agents, 24 (6): 536547, 2004.

2- BART P.H.J. and THOMMA BRUNO P.A.: Cammue and Karin Thevissen Planta, 216 (2): 193-202, 2002.

3- PEARCE G., YAMAGUCHI Y., MUNSKE G. and RYAN C.A.: "Structure-activity studies of AtPep1, a plant peptide signal involved in the innate immune response". Peptides, 29 (12): 2083-9, 2008.

4- GARCIA J.R., KRAUSE A., SCHULZ S., RODRIGUEZJIMENEZ F.J., KLUVER E., et al.: Human beta-defensin 4: A novel inducible peptide with a specific salt-sensitive spectrum of antimicrobial activity. FASEB J., 15: 1819$1821,2001$.

5- YAMAGUCHI Y., NAGASE T., MAKITA R., FUKUHARA S., TOMITA T., et al.: Identification of multiple novel epididymis-specific beta-defensin isoforms in humans and mice. J. Immunol., 169: 2516-2523, 2002.

6- LEHRER R.I.: Primate defensins. Nat. Rev. Microbiol., 2: 727-738, 2004.

7- HARDER J., BARTELS J., CHRISTOPHERS E. and SCHRODER J.M.: "Isolation and characterization of human beta -defensin-3, a novel human inducible peptide antibiotic." The Journal of Biological Chemistry, 276 (8): 5707-13, 2001.

8- KEYS D.N., AU-YOUNG J.K. and FEKETE R.A.: TaqMan Array Cards in pharmaceutical research. Methods Mol. Biol., 632: 87-98, 2010.

9- AKIRA S.: Toll-like receptor signaling. J. Biol. Chem., 278: 38105-8, 2003.

10- SAWAMURA D., GOTO M., SHIBAKI A., et al.: Beta defensin-3 engineered epidermis shows highly protective effect for bacterial infection. Gene Ther., 12: 857-61, 2005.

11-De JONGH G.J., ZEEUWEN P.L.J.M., KUCHAREKOVA M., et al.: High expression levels of keratinocyte antimicrobial proteins in psoriasis compared with atopic dermatitis. J. Invest Dermatol., 125: 1163-73, 2005.

12- ZHENG Y., NIYONSABA F., USHIO H., et al.: Microbicidal protein psoriasin is a multifunctional modulator of neutrophil activation. Immunology, 124: 357-67, 2008.

13-ZANGER P., HOLZER J., SCHLEUCHER R., STEFFEN H., SCHITTE K.B., et al.: Constitutive expression of the antimicrobial peptide RNase 7 is associated with Staphylococcus aureus infection of the skin. J Infect Dis., 200: 1907-15, 2009. 
14- ALY R.: Ecology and epidemiology of dermatophyte infections. J. Am. Acad. Dermatol., 31: S21-5, 1994

15- LÓPEZ-GARCÍA B., LEE P.H., YAMASAKI K. and GALLO R.L.: Anti-fungal activity of cathelicidins and their potential role in Candida albicans skin infection. J. Invest Dermatol., 125: 108-15, 2005.

16-LÓPEZ-GARCÍA B., PHILLIP H.A. LEE and GALLO R.L.: Expression and potential function of cathelicidin antimicrobial peptides in dermatophytosis and tinea versicolor. Journal of antimicrobial Chemotherapy, 57: 877-882, 2006.
17- BRASCH J., MÖRIG A., NEUMANN B. and PROKSCH E.: Expression of antimicrobial peptides and toll-like receptors is increased in tinea and pityriasis versicolor. Mycoses, 57: 147-152, 2014.

18- DONNARUMA G., PAOLETI I. BUOMMINO, ORLANDO M., TUFANO M.A. and BARONI A.: Malaseszia furfur induces the expression of beta-defnsin 2 in human keratinocytes in a protein kinase C-dependent manner. Arch. Dematol. Res., 295 (11): 474-481, 2004.

\title{
بيتا ديفينسين Y فى عدوى الجلد الفطرية
}

\author{
البيتيدات المضادة للميكروبات هو مكون عظيم المناعة الفطرية ضد العدوى وانتاجهم أما أساسى أو مستحث اعتماداً على مجال واسع \\ من الخواص مثل نوع الميكروب ونوع الخلية. \\ مجموعتان أسعاسيتان من البييتيدات تم دراستهم بتوسع فى الجلد البشرى وهما البيتا ديفينسين Y والكاثيليشين. \\ دراسات عديدة تمت وأظهرت الدور الحيوى لهذه البيتيدات المضادة للميكروبات فى العدوى البكتيرية ولكن دراسات قليلة أقرت بخصوص \\ العدوى الفطرية. \\ الهدف من هذه الدراسة: هو فحص التعبير الجينى النعيجى الليتا ديفينسين ب فى الجلد المصاب بالتينيا الملونة والتينيا الحلقية ومن

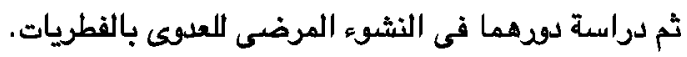 \\ أظهرت هذه الدراسة فروق ذات دلالة إحصائية في التعبير الجينى لهذه البيبتيدات فى الجلد المصاب مقارتة بالجلد السليم (العينة الضـابطة). \\ لم تظهر الرسالة أى فروق ذات دلالة إحصائية بخصوص التعبير الجينى للكاثليسيدين للجلد المصاب لم يستتج فرق بين الاناث والذكو. \\ لم تظهر الدراسة فرق ذات دلالة إحصائية بين الذكو والاناث بخصوص التعبير الجينى لأى من البييتيدين فى الجلد المصاب بالتينيا
}

لم تظهر الدراسة أيضاً ارتباط ذو دلالة إحصائية بين التعبير الجينى للكاثيليشيدن والعمر، مدة المرض، ومعدل الارتداد في مرضى التينيا الملونة أو الحلقية.

وقجد أيضاً ارتفاع ذو دلالة إحصائية للتعبير الجينى للبيتا ديفينسين Y في الجلد المصاب مقارنة بالجلد السليم مما يؤكد دودهما فى

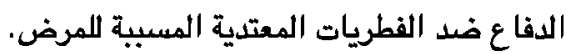

